\title{
A TONELAGEM DA FROTA DA COMPANHIA GERAL DO GRÃO-PARÁ E MARANHÃO $(1755-1788)\left(^{\star}\right)$.
}

Questão vital para a manutenção e crescimento orgânico ta Companhia era o transporte. O problema foi pôsto pela Junta da Administração na ordem do dia em caráter de urgência. A vida da gigantesca emprêsa projetada dependia, verdadeiramente, da solução encontrada para semelhante proposição, sem dúvída substancial. A montagem de uma vigorosa frota mercante para o tráfico atlântico à distância, para a transportação das mercadorias tropicais comerciáveis e dos artigos europeus, mostrava-se tarefa difícil. Financiamento, escassez crônica de capitais vivos, tonelagens, organização das unidades com pessoal qualificado, bem como o perfazimento das rotas do Mar do Norte, do Báltico e do Mediterrâneo para a redistribuição dos produtos tropicais pelos mercados europeus, constituiam embaraçoso problema. O estabelecimento de uma rêde regular de comunicações marítimas entre Lisboa e as diferentes áreas geo-econômicas do patrimônio ultramarino no Atlântico afro-brasileiro era, no entanto, primacial. Por isso mesmo o govêrno da Companhia encarou o assunto de frente, disposto a solucionar a delicada e dispendiosa pendência.

Claro é que seria enormemente extravagante, senão impossível, mandar construir uma frota logo após a confirmação régia do estabelecimento da Companhia, em 7 de junho de 1755 (1) . Ao contratempo da espera juntava-se o desapropositado empate de capital ou o desvantajoso financiamento. Acresce, outrossim, o inconveniente que poderia resultar de semelhante encomenda, uma vez que tudo aconselhava a organização de uma marinha mercante, cujo crescimento deveria ser ajustado à tonelagem das mercadorias a transportar. Os comboios,

\footnotetext{
(*). - Comunicação apresentada ao Congresso Internacional de História dos Descobrimentos (Lisboa, 4 a 12 de stembro de 1960) (Nota da Redaçáo).

(1). - Cf. Instituição da Companhia Geral do Grão-Pará e Maranmão, págs. 19 e seg. Lisboa, 1755.
} 
para não serem deficitários, seriam assentados de acôrdo com os montantes exportáveis de São Luís, Belém, Cacheu, Bissau, Angola e ilhas de Cabo Verde, bem como em função da maior ou menor aceitação dos produtos tropicais nas praças consumidoras da Europa. A emprêsa colonial, para ser grande, começaria pequena.

Parelhamente a êsse amontoado de empecilhos, havia ainda o estôrvo da pirataria. A riqueza das carregações das rotas atlânticas despertaria, certamente, o apetite dos corsários e piratas. As frotas do algodão, do cacau e dos demais produtos tropicais, grandemente desejados, tinham de ser protegidas por certas fragatas de guerra. A amplidão econômica das áreas coloniais tinha, igualmente, que ser escorada contra as prováveis investidas da concorrência imperialista das grandes potências. A partilha política e econômica do Atlântico impunha segurança militar, complementação autêntica e necessária do tráfico colonial.

Enorme, pois, a demanda do comércio entre Lisboa e o últramar. O sistema de transporte, que haveria de fazer a fortuna da Companhia e da colônia, pelo entrelaçamento das longínquas e diferentes áreas do império dividido por quatro continentes, não foi descuidado. Logo que se cogitou da montagem da emprêsa, o problema foi maduramente pensado, sinal evidente da circunspeção do planejamento da sociedade mercantil.

Vejam-se, por exemplo, os parágrafos nono, décimo e décimo quarto dos estatutos da Companhia. Estabelece aquêle a doação régia de uma área de praia no sítio da Boa Vista, em Lisboa, onde a emprêsa tinha urgente necessidade de edificar estaleiros para seus navios e armazéns

\footnotetext{
"para a guarda de tudo o que for a elles pertencente, e estancia para conservarem suas madeiras, fabricando-se tudo em fórma, que não cause à vizinhança prejuizo, que seja attendivel" (2).
}

O parágrafo décimo, por sua vez, dispunha que a Companhia teria o privilégio de mandar construir seus navios mercantes e de guerra, em Portugal e no Estado do Grão-Pará e Maranhão, podendo para isso mandar cortar onde entendessetôda a madeira que lhe fôsse necessária, pagando, porém, o seu justo valor aos respectivos donos (3). O parágrafo décimo quarto completava, afinal, a benesse régia, pois em obe-

(2). 一 Ibidem, $\$ 9 .{ }^{\circ}$, pág. 6 .

(3). - Tbidem, idem, § $100^{\circ}$. 
diência ao que dispunha, a Corôa fêz mercê e doação à Companhia de duas fragatas de guerra (4) para os comboios e sucessivo serviço de suas frotas. Trata-se das naus Nossa Senhora da Atalaia e Nossa Senhora das Mercês, destinadas a dar cobertura militar aos navios mercantes contra as prováveis agressões da pirataria; deviam também servir para o transporte das carregações tôdas as vêzes que se tornasse conveniente (5).

Promulgado o referido alvará régio de confirmação da sociedade, a 7 de junho de 1755, a Junta da Administração enviou logo no comêço de agôsto dêsse mesmo ano, ao Estado do GrãoPará e Maranhão, o hiate São João da Cruz com o aviso da criação da emprêsa colonial. O navio, fretado a João Faria Pereira, navegou sob o comando do capitão João da Silva, segundo consta do "Diário" (6) e do "Livro dos Balanços" (7) da Companhia.

Comprando, primeiro, construindo e reformando, depois, em seus estaleiros do reino e do ultramar, a emprêsa de comércio e navegação conseguiu, progressivamente, montar uma poderosa frota mercante, cujos navios navegavam com regularidade nas rotas do Atlântico afro-brasileiro que demandavam Cacheu, Bissau, Angola, ilhas de Cabo Verde, Pará e Maranhão, pelos desejados produtos tropicais. A tessitura do tráfico marítimo era completada pela mecânica da redistribuição das mercadorias de proveniência ultramarina, negociadas nos entrepostos de Londres, Antuérpia, Roterdão, Hamburgo, Cadiz, Marselha e Gênova (8) . O portentoso giro comercial era completado pelo tráfico de cabotagem e patrulhamento das costas vulneráveis do Brasil e do ocidente africano, onde eram empregadas embarcações menores (9).

Tarefa difícil, senão impossível, dada a escassez de fontes, é a organização de um quadro demonstrativo completo da tonelagem da frota da Companhia, acompanhado da relação dos capitães de navios, anos de comando, preços de custo, tipos de barcos e respectivas rotas em que se achavam em operação comercial ou de cobertura militar.

Os elementos guardados nos arquivos de Lisboa oferecem, porém, magníficos informes, embora incompletos, que nos per-

(4). - "Huma de quarenta até cincoenta peças; outra de trinta até quarenta". (Ibiàem, § 14. ${ }^{\circ}$, pág. 8).

(5) . - A.H.M.F. - L.B.C.G.P.M

(6). - Ibidem, D.C.G.P.M. - A, n. ${ }^{\circ}$ 3, de 13 de agôsto de 1755 .

(7). - Ibidem, L.B.C.G.P.M., demonstração n.o 10, 1756.

(8). - A.H.M.F. - C.N.C.G.P.M. $\rightarrow$ Livro n.o 96; A.H.U.C.P., n.o 33 (1772).

(9). - Ibidem, L.R.E.C.C.G.P.M., livro n.o 91 . 
mitem observar melhor a organização crescente dos poderosos comboios da Companhia durante o tempo do seu giro comercial, que se estende de agôsto de 1755 a janeiro de 1778 . Vejamse, por exemplo, as relações seguintes, elucidativas da baralhada questão marítima (10).

Repare-se no elevado número de navios. Quer-nos parecer, no entanto, que alguns dêles acham-se em duplicação. Restaurados nos estaleiros do reino e do ultramar, algumas embarcações mudariam de nome ou, conforme o caso, de tipo de navio. Vejam-se os nomes e tipos dos barcos apurados nos quadros demonstrativos. A galera Nossa Senhora da Conceição (17), por exemplo, navegava no Atlântico afro-brasileiro desde 1759, fazendo carga e descarga nas Ilhas de Cabo Verde e nos portos de Belém e São Luís. Em 1759, portanto no mesmo ano, encontrava-se nas rotas do Pará, Maranhão e Angola uma sumaca com o mesmo nome - Nossa Senhora da Conceição. Afigurase-nos tratar-se do mesmo navio, uma vez que o capitão Antônio Pontes Lisboa acha-se comandando a galera e a sumaca. Os preços de custo, porém, são diferentes, fato que torna a questão ainda mais arrevesada. A galera, conhecida como a segunda, em 1760, e perdida em 1769, custou à Companhia a importância de $5.149 \$ 448$ réis. A sumaca, entretanto, figura nos Balanços da emprêsa como sendo adquirida em 1772 pela quantia de $2.802 \$ 825$ réis (18). Na demonstração do ano seguinte, em 1773, a escrituração da Companhia registra a compra de uma sumaca - Nossa Senhora da Conceição - pelo preço de .... $3.147 \$ 025$ réis (19). Em 1774 a sociedade adquiriu uma chalupa do mesmo nome pela importância de $1.050 \$ 523$ réis (20). Anos antes, em 1771, a Junta da Administração já havia adquirido uma galera, também chamada Nossa Senhora da Conceição, pela quantia de $5.696 \$ 000$ réis, consoante registro que figura no Balanço da emprêsa nesse ano (21). Haverá, aqui, duplicidade

(10) . - Quadros demonstrativos organizados com os elementos extraídos dos seguintes arquivos de Lisboa: A.C.M.L. - M.N. Livros n.os 1, 2 e 4 (17721778); A.H.U. $\rightarrow$ M.N. n.os 25 (1760-1764), 26 (1764-1769), 28 (1772-1773), 29 (1774-1775), 30 (1775-1777) e 31 (1778-1779); C.P. n.os 35 (1774-1776), 37 (1777-1778) e 38 (1778); A.H.M.F. - M. n.o A, Liv. 62; L. Car. C.G.P.M. n.0 45 A; L.C.C.G.P.M.E. n.o 73; C.N.C.G.P.M. - Liv. n.o 99; L.B.C.G. P. M. — n. ${ }^{\circ} 76$.

(17). - Nossa Senhora da Conceição era a Padroeira do Reino e Protetora da Companhia. (Cf. Instituição..., § $10^{\circ}$ e 21).

(18). $\rightarrow$ Cf. L.B.C.G.P.M. Liv. n.o 76, 1772 .

(19). - Tbidem, idem, 1773

(20) . - Ibidem, idem, 1774 .

(21) . - Ibidem, idem, 1771 


\section{A TONELAGEM DA FROTA DA COMPANHIA}

(1755-1778)

\begin{tabular}{|c|c|c|c|c|c|}
\hline $\begin{array}{l}\text { Nomes dos } \\
\text { navios }\end{array}$ & $\begin{array}{l}\text { Nomes dos } \\
\text { capitries }\end{array}$ & $\begin{array}{l}\text { Preços de custo } \\
\text { dos navios (réis) }\end{array}$ & $\begin{array}{l}\text { Anos de coman- } \\
\text { do }\end{array}$ & $\begin{array}{c}\text { Rotas de nave- } \\
\text { gação }\end{array}$ & $\begin{array}{l}\text { Tipos de } \\
\text { navios }\end{array}$ \\
\hline $\begin{array}{l}\text { Santa Anna e São } \\
\text { Francisco Xavier }\end{array}$ & $\begin{array}{l}\text { Valério Duarte Gomes } \\
\text { Bernardo Franco }\end{array}$ & $11.679 \$ 408$ & $\begin{array}{l}1756,1757,175 \overline{1} \\
1760,1761,1762, \\
1765,1766,1767 \mathrm{e} \\
1768 \\
1770, \quad 1771,1772 \\
1773,1775 \text { e } 1776\end{array}$ & Para & Nau \\
\hline $\begin{array}{l}\text { Nossa Senhora da Ma- } \\
\text { dre de Deus, São José } \\
\text { e Almas }\end{array}$ & $\begin{array}{l}\text { João de Freitas Mon- } \\
\quad \text { teiro } \\
\text { Francisco Serra } \\
\text { Manuel Travassos }\end{array}$ & $10.267 \$ 728$ & $\begin{array}{l}1756 \text { e } 1760 \\
1762 \\
1763,1764,1765 \\
1766,1767,1770 \text { e } \\
1772\end{array}$ & $\begin{array}{l}\text { Pará e } \\
\text { Maranhão }\end{array}$ & $\mathrm{Nau}$ \\
\hline São Luis & $\begin{array}{l}\text { José de Carvalho } \\
\text { Manuel Gonçalves Sal- } \\
\quad \text { gado }\end{array}$ & $5.353 \$ 857$ & 1759 & $\begin{array}{l}\text { Pará e } \\
\text { Maranháo }\end{array}$ & Galera \\
\hline São Paulo & $\begin{array}{l}\text { José Manuel Travassos } \\
\text { Gerônimo Gonçalves } \\
\text { Joaquim Ribeiro Duar- } \\
\text { te } \\
\text { Domingos Antônio } \\
\text { Chaves }\end{array}$ & $1.317 \$ 564$ & $\begin{array}{l}1760 \text { e } 1761 \\
1772 \\
1773 \\
1774, \quad 1775\end{array}$ & $\begin{array}{l}\text { Pará, } \\
\text { Maranhão, } \\
\text { Bissau e } \\
\text { Cacheu }\end{array}$ & Bergantim \\
\hline São Francisco Xavier & \begin{tabular}{|l} 
Francisco João \\
Manuel da Silva \\
Manuel da Silva Tho- \\
más \\
Francisco Jaques Cal- \\
deira
\end{tabular} & $18.574 \$ 921$ & $\begin{array}{l}1763 \\
1767,1768 \text { e } 1769 \\
1770,1772,1773 \\
1775 \text { e } 1776 \\
1776 \text { (2a. viagem) } \\
1778\end{array}$ & $\begin{array}{l}\text { Pará, } \\
\text { Maranhão, } \\
\text { Bissau e } \\
\text { Cacheu }\end{array}$ & Corveta \\
\hline
\end{tabular}




\begin{tabular}{|c|c|c|c|c|c|}
\hline São Pedro Gonçalves & $\begin{array}{l}\text { Mernardo Franco } \\
\text { Miguel Pereira da Cos- } \\
\text { ta } \\
\text { Ignácio Luís da Silva } \\
\text { João do Espirito San- } \\
\text { to }\end{array}$ & $14.343 \$ 370$ & 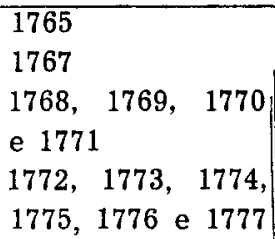 & $\begin{array}{l}\text { Pará, } \\
\text { Maranhão, } \\
\text { Bissau e } \\
\text { Cacheu }\end{array}$ & Corveta \\
\hline $\begin{array}{l}\text { Nossa Senhora da Oli- } \\
\text { veira }\end{array}$ & $\begin{array}{l}\text { Antônio José de Car- } \\
\quad \text { valho } \\
\text { Mnauel Luís do Cabo } \\
\text { Cipriano Madureira } \\
\text { José Dias Pereira } \\
\text { Joaquim da Costa Cor- } \\
\quad \text { tezão }\end{array}$ & $15.174 \$ 684$ & $\begin{array}{l}1768 \\
1772,1773 \text { e } 1775 \\
1777 \\
1777 \\
1778\end{array}$ & $\begin{array}{l}\text { Pará, } \\
\text { Maranhão } \\
\text { e Bissau }\end{array}$ & Corveta \\
\hline $\begin{array}{l}\text { Nossa Senhora da Con- } \\
\text { ceição (1a. ou 2a.?) }\end{array}$ & $\begin{array}{l}\text { Antônio Pontes Lisboa } \\
\text { Joaquim José das Mer- } \\
\text { cês } \\
\text { Francisco Duarte Ser- } \\
\text { ra }\end{array}$ & $5.149 \$ 448$ & $\begin{array}{l}1755 \text { e } 1759 \\
1762 \\
1773\end{array}$ & $\begin{array}{l}\text { Pará, } \\
\text { Maranhäo } \\
\text { e Ilhas } \\
\text { de Cabo } \\
\text { Verde }\end{array}$ & Galera \\
\hline $\begin{array}{l}\text { Nossa Senhora da Con- } \\
\text { ceição ( } 2 \mathrm{a} \text {. ou } 3 \mathrm{a} . ?)\end{array}$ & $\begin{array}{l}\text { Miguel da Costa } \\
\text { Francisco de Carvalho } \\
\text { Miguel Pereira da Cos- } \\
\text { ta } \\
\text { José Antônio Lisboa } \\
\text { Veríssimo Duarte Rosa }\end{array}$ & $5.696 \$ 000$ & $\begin{array}{l}1771 \text { e } 1773 \\
1773 \\
1773 \\
1777 \\
1777 \text { (2a. viagem) }\end{array}$ & $\begin{array}{l}\text { Pará, } \\
\text { Maranhão } \\
\text { e Ilhas } \\
\text { de Cabo } \\
\text { Verde }\end{array}$ & Galera (11) \\
\hline $\begin{array}{l}\text { Nossa Senhora da Pje- } \\
\text { dade }\end{array}$ & Manuel Travassos & $7.569 \$ 600$ & 1772 e 1774 & $\begin{array}{l}\text { Maranhão } \\
\text { e Ilhas } \\
\text { de Cabo } \\
\text { Verde }\end{array}$ & Galera \\
\hline
\end{tabular}

(11). - Há uma sumaca do mesmo nome em 1772. 


\begin{tabular}{|c|c|c|c|c|c|}
\hline $\begin{array}{l}\text { Santa Anna e São Joa- } \\
\text { quim }\end{array}$ & $\begin{array}{l}\text { Severiano Gonçalves } \\
\text { José de Oliveira Bu- } \\
\text { lhăo }\end{array}$ & $4.700 \$ 000$ & $\begin{array}{l}1757 \text { e } 1774 \\
1776 \text { e } 1777\end{array}$ & $\begin{array}{l}\text { Pará e } \\
\text { Maranhão }\end{array}$ & Galera \\
\hline $\begin{array}{l}\text { Nossa Senhora do Ro- } \\
\text { sário }\end{array}$ & Julião "Potier" (?) & $4.084 \$ 015$ & 1765 e 1774 & $\begin{array}{l}\text { Maranhão, } \\
\text { Parnaíba e Pará }\end{array}$ & Escuna \\
\hline São Joaquim & & $1.768 \$ 918$ & & & Hiate \\
\hline $\begin{array}{l}\text { Nossa Senhora de } \mathrm{Na}- \\
\text { zareth }\end{array}$ & $\begin{array}{l}\text { José Francisco de } \mathrm{Ma}- \\
\text { cedo } \\
\text { Antônio Florêncio }\end{array}$ & $1.246 \$ 746$ & $\begin{array}{l}1766,1773 \text { e } 1776 \\
1777\end{array}$ & $\begin{array}{l}\text { Parnaíba, } \\
\text { Pará e } \\
\text { Maranhão } \\
\end{array}$ & Chalupa \\
\hline $\begin{array}{l}\text { Nossa Senhora da Pie- } \\
\text { dade }\end{array}$ & José Manuel & $1.116 \$ 194$ & 1767 e 1773 & $\begin{array}{l}\text { Pará, Maranhão e } \\
\text { Parnaíba }\end{array}$ & Chalupa (12) \\
\hline $\begin{array}{l}\text { Nossa Senhora da Ar- } \\
\text { rábida }\end{array}$ & & $1.187 \$ 096$ & 1767 & $\begin{array}{l}\text { Parnaíba, Pará e } \\
\text { Maranhäo }\end{array}$ & Chalupa \\
\hline $\begin{array}{l}\text { Nossa Senhora da Boa } \\
\text { Viagem }\end{array}$ & $\begin{array}{l}\text { Antônio Luís da Pie- } \\
\text { dade } \\
\text { Feliciano dos Santos }\end{array}$ & $1.643 \$ 953$ & $\begin{array}{l}1768 \text { e } 1774 \\
1775\end{array}$ & Maranhão & Chalupa \\
\hline $\begin{array}{l}\text { Nossa Senhora do Bom } \\
\text { Sucesso }\end{array}$ & Jacinto Rodrigues & $1.615 \$ 093$ & 1756 e 1768 & Pará & Chalupa \\
\hline Lancha Nova & & $358 \$ 902$ & 1767 & Cacheu & Lancha \\
\hline Santa Família & & $2.322 \$ 588$ & & $\begin{array}{l}\text { Parnaíba, Pará e } \\
\text { Maranhão }\end{array}$ & Sumaca \\
\hline $\begin{array}{l}\text { Nossa Senhora do Bom } \\
\text { Despacho }\end{array}$ & & $2.389 \$ 816$ & 1768 & \begin{tabular}{|l} 
Cacheu e \\
Bissau
\end{tabular} & Hiate \\
\hline
\end{tabular}

(12). - Há uma galera do mesmo nome em 1767. 


\begin{tabular}{|c|c|c|c|c|c|}
\hline $\begin{array}{l}\text { Nossa Senhora da Boa } \\
\text { Nova }\end{array}$ & 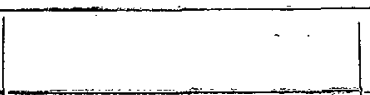 & $2.389 \$ 816$ & 1768 & $\begin{array}{l}\text { Cacheu e } \\
\text { Bissau }\end{array}$ & Hiate \\
\hline $\begin{array}{l}\text { Nossa Senhora da Con- } \\
\text { ceição e Almas }\end{array}$ & José Gomes Ribeiro & $2.802 \$ 825$ & 1762 e 1764 & $\begin{array}{l}\text { Pará e } \\
\text { Maranhão }\end{array}$ & Sumaca \\
\hline $\begin{array}{l}\text { Nossa Senhora da Vi- } \\
\text { da }\end{array}$ & & $1.863 \$ 068$ & & $\begin{array}{l}\text { Parnaíba } \\
\text { e Pará }\end{array}$ & Chalupa \\
\hline $\begin{array}{l}\text { Nossa Senhora da Saú- } \\
\text { de }\end{array}$ & & $1.863 \$ 068$ & & $\begin{array}{l}\text { Parnaiba } \\
\text { e Pará }\end{array}$ & Chalupa \\
\hline $\begin{array}{l}\text { "Francesa comprada } \\
\text { em Cacheu" }\end{array}$ & & $446 \$ 400$ & & Cacheu & Chalupa \\
\hline $\begin{array}{l}\text { Nossa Senhora da Con- } \\
\text { ceição }\end{array}$ & Antônio Pontes Lisboa & $3.147 \$ 095$ & 1759 e 1773 & $\begin{array}{l}\text { Parnaíba, } \\
\text { Pará, Maranhão } \\
\text { e Angola }\end{array}$ & Sumaca \\
\hline $\begin{array}{l}\text { Nossa Senhora do So- } \\
\text { corro }\end{array}$ & & $356 \$ 103$ & 1774 & & Escuna \\
\hline $\begin{array}{l}\text { Nossa Senhora da Aju- } \\
\text { da }\end{array}$ & & $655 \$ 610$ & & $\begin{array}{l}\text { Parnaíba } \\
\text { e Pará }\end{array}$ & Chalupa \\
\hline $\begin{array}{l}\text { Nossa Senhora da } \mathrm{Pe}- \\
\text { nha de França }\end{array}$ & José Correa Lisboa & $612 \$ 000$ & $\begin{array}{l}1759 \\
1778 \\
\end{array}$ & $\begin{array}{l}\text { Maranhão } \\
\text { e Pará }\end{array}$ & Lancha \\
\hline $\begin{array}{l}\text { Nossa Senhora dos } \\
\text { Prazeres }\end{array}$ & & $2.577 \$ 500$ & 1774 & Maranhão & Sumaca \\
\hline $\begin{array}{l}\text { Nossa Senhora da Con- } \\
\text { ceição }\end{array}$ & $\begin{array}{l}\text { Francisco Duarte Ser- } \\
\text { ra }\end{array}$ & $1.050 \$ 523$ & 1755,1773 e 1774 & $\begin{array}{l}\text { Parnaíba } \\
\text { e Pará }\end{array}$ & Chalupa \\
\hline São José & $\begin{array}{l}\text { José Ferreira de Aze- } \\
\text { vedo } \\
\text { Luís Ferreira Braga. }\end{array}$ & $4.842 \$ 552$ & $\begin{array}{l}1755,1756,1758 \mathrm{e} \\
1760 \\
1763\end{array}$ & $\begin{array}{l}\text { Pará, } \\
\text { Maranhäo, } \\
\text { Bissau e Cacheu }\end{array}$ & Galera \\
\hline $\begin{array}{l}\text { Nossa Senhora da Ata- } \\
\text { laia e Senhora do Bom } \\
\text { Fim }\end{array}$ & & $5.192 \$ 208$ & 1756 & $\begin{array}{l}\text { Pará e } \\
\text { Maranhão }\end{array}$ & Galera (13) \\
\hline
\end{tabular}

(13). - Há uma galera com emste nome perdida em Angola em 1759 : 


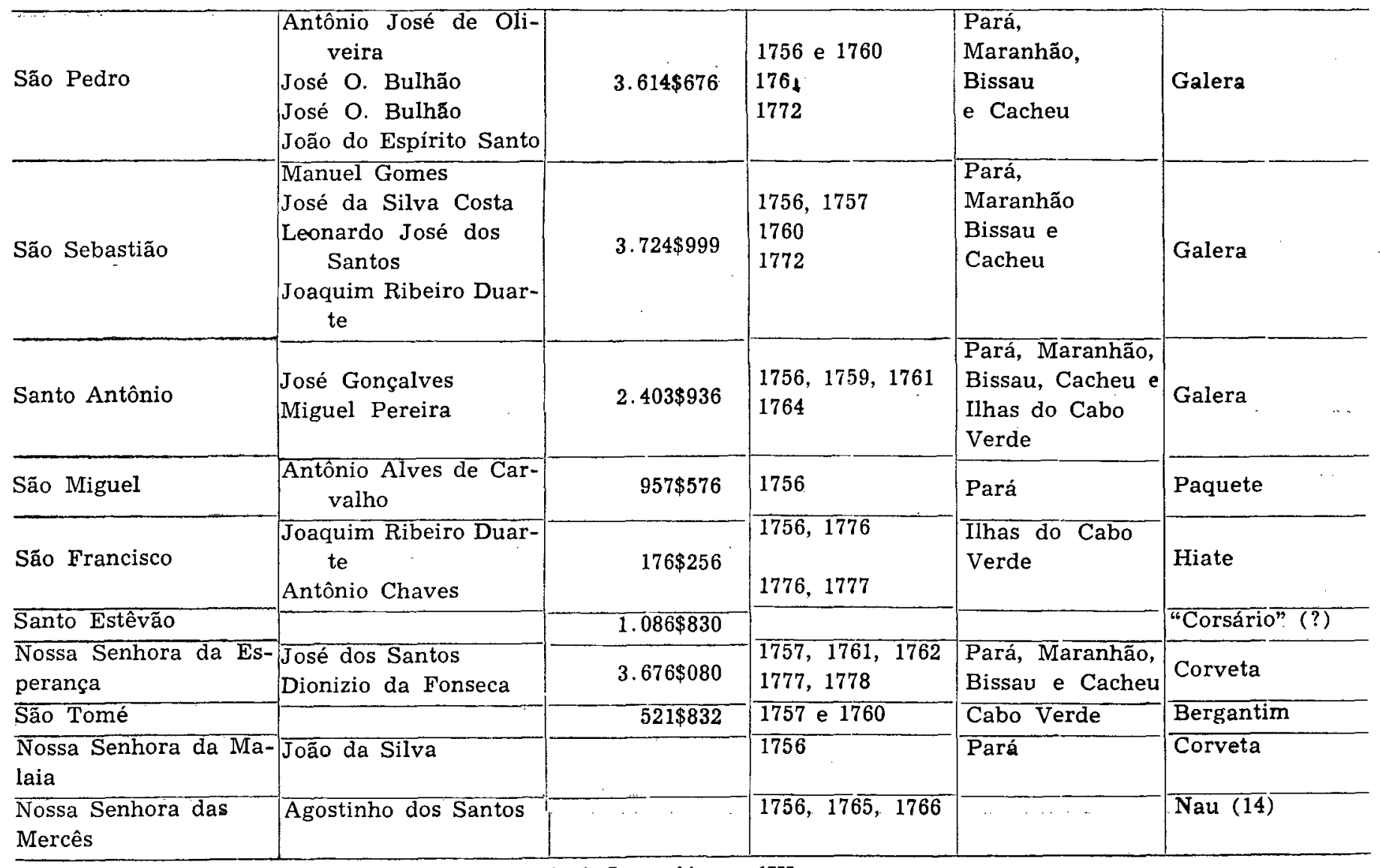

(14). - Só pode ser a nau de guerra doada pela Corôa à Companhia em 1755

(Cf. Instituição..., § 14) 


\begin{tabular}{|c|c|c|c|c|c|}
\hline $\begin{array}{l}\text { Nossa Senhora da Ata- } \\
\text { laia }\end{array}$ & $\begin{array}{l}\text { Agostinho dos Santos } \\
\text { Francisco Duarte Ser- } \\
\text { ra }\end{array}$ & $2.189 \$ 670$ & 1757,1761 & $\begin{array}{l}\text { Pará, } \\
\text { Maranhão } \\
\text { e Angola }\end{array}$ & Galera (15) \\
\hline $\begin{array}{l}\text { Nossa Senhora das Ne- } \\
\text { ves }\end{array}$ & $\begin{array}{l}\text { João da Silva } \\
\text { Agostinho dos Santos }\end{array}$ & & $\begin{array}{ll}1759, & 1760 \\
1764, & 1767\end{array}$ & Pará & Galera \\
\hline $\begin{array}{l}\text { Nossa Senhora do Ca- } \\
\text { bo }\end{array}$ & Manuel da Cunha & $6.4 \overline{69 \$ 248}$ & $\begin{array}{|lll|}1761, & 1762, & 1765 \\
1767, & 1768, & 1772\end{array}$ & $\begin{array}{l}\text { Pará, Maranhão, } \\
\text { Bissau e Angola }\end{array}$ & Navio \\
\hline São João Batista & $\begin{array}{l}\text { José de Oliveira Bu- } \\
\text { lhão } \\
\text { Veríssimo Duarte }\end{array}$ & & $\begin{array}{l}1762,1764 \\
1772\end{array}$ & $\begin{array}{l}\text { Pará, Maranhão } \\
\text { e Angola }\end{array}$ & Navio \\
\hline $\begin{array}{l}\text { Nossa Senhora das Ne- } \\
\text { cessidades }\end{array}$ & José dos Santos & $4.005 \$ 910$ & 1760 e 1763 & $\begin{array}{l}\text { Pará, Maranhão } \\
\text { e Cacheu }\end{array}$ & Corveta \\
\hline São Lázaro & $\begin{array}{l}\text { Gaspar dos Reis } \\
\text { José O. Bulhão } \\
\text { José de Oliveira }\end{array}$ & $2.637 \$ 312$ & $\begin{array}{l}1764 \\
1772\end{array}$ & $\begin{array}{l}\text { Pará, Maranhão } \\
\text { e Angola }\end{array}$ & Navio \\
\hline $\begin{array}{l}\text { Nossa Senhora da Gló- } \\
\text { ria }\end{array}$ & Joaquim das Mercês & & 1773 e 1774 & $\overline{\text { Pará }}$ & Lambote (16) \\
\hline $\begin{array}{l}\text { Nossa Senhora da Es- } \\
\text { perança e Santa Paula }\end{array}$ & $\begin{array}{l}\text { Dionizio Cunha da } \\
\text { Fonseca }\end{array}$ & & 1775 & $\begin{array}{l}\text { Maranhão } \\
\text { e Pará }\end{array}$ & \\
\hline $\begin{array}{l}\text { São João, Santo Antô- } \\
\text { nio e Almas }\end{array}$ & Manuel José de Irias & & 1775 & $\begin{array}{l}\text { Maranhão } \\
\text { e Pará }\end{array}$ & Corveta \\
\hline $\begin{array}{l}\text { Nossa Senhora da Con- } \\
\text { ceição e São José }\end{array}$ & José Antônio Lisboa & & 1775 & $\begin{array}{l}\text { Maranhão } \\
\text { e Fará }\end{array}$ & Corveta \\
\hline $\begin{array}{l}\text { Nossa Senhora de Be- } \\
\text { lém }\end{array}$ & $\begin{array}{l}\text { Sebastião Alberto } \\
\text { Manuel da Cunha }\end{array}$ & & 1775 & $\begin{array}{l}\text { Maranhão } \\
\text { e Pará }\end{array}$ & Corveta \\
\hline
\end{tabular}

(15). - Trata-se da nau de guerra que a Companhia recebeu da realeza em 1755? (Ibldem, Idem).

(16). - Embarcações pequenas "que giram na Guinê". 


\begin{tabular}{|c|c|c|c|c|c|}
\hline $\begin{array}{l}\text { Santo Antônio e Del- } \\
\text { fim }\end{array}$ & $\begin{array}{l}\text { Lourenço Gomes dos } \\
\text { Santos }\end{array}$ & & 1776 & $\begin{array}{l}\text { Pará e } \\
\text { Maranhão }\end{array}$ & Corveta \\
\hline Grão-Pará & $\begin{array}{l}\text { Manuel da Silva Tho- } \\
\text { más }\end{array}$ & & 1777 & $\begin{array}{l}\text { Pará e } \\
\text { Maranhão }\end{array}$ & Nau \\
\hline $\begin{array}{l}\text { Santa Anna e São Do- } \\
\text { mingos }\end{array}$ & $\begin{array}{l}\text { José das Neves } \\
\text { José de Oliveira Bu- } \\
\text { lhão }\end{array}$ & & 1777 (2a. viagem) & Pará & Corveta \\
\hline $\begin{array}{l}\text { São João Batista } \\
\text { (2a.?) }\end{array}$ & & $2.700 \$ 745$ & 1761 & Maranhão & Navio \\
\hline São Domingos & & $1.882 \$ 308$ & 1761 & Maranhão & Galera \\
\hline São Marçal & & $1.626 \$ 798$ & 1761 & Maranhão & Bergantim \\
\hline $\begin{array}{l}\text { Santa Ana, São José e } \\
\text { Almas }\end{array}$ & & & & Maranhão & Nau \\
\hline $\begin{array}{l}\text { Santíssimo Sacramen- } \\
\text { to }\end{array}$ & Gaspar dos Santos & & 1774 & Maranhão & Nau \\
\hline $\begin{array}{l}\text { Nossa Senhora do } \mathrm{Li}- \\
\text { vramento }\end{array}$ & Francisco de Sales & & 1777 & Maranhão & Corveta \\
\hline Prazeres & & & 1776 & Maranhão & Nau \\
\hline Santa Isabel & & & 1775 & Maranhão & Galera \\
\hline $\begin{array}{l}\text { Nossa Senhora do Ro- } \\
\text { sário e Santo Antônio }\end{array}$ & . & & $\overline{1776}$ & Maranhāo & Galera \\
\hline $\begin{array}{l}\text { Nossa Senhora da Pie- } \\
\text { dade e Amizade }\end{array}$ & José Manuel & & 1772 & Maranhão & Corveta \\
\hline $\begin{array}{l}\text { Boa Viagem e Corpo } \\
\text { Santo }\end{array}$ & & & & Maranhão & Corveta \\
\hline
\end{tabular}




\begin{tabular}{|c|c|c|c|c|}
\hline Nazaré e Santa Anna & & & Maranhão & Corveta \\
\hline $\begin{array}{l}\text { Nossa Senhora do } \\
\text { Monte Carmo }\end{array}$ & $\begin{array}{l}\text { Joăo Pedro } \\
\text { S. Alberto } \\
\text { Dionizio dos Reis }\end{array}$ & $\begin{array}{l}1773 \\
177 b \\
1777\end{array}$ & $\begin{array}{l}\text { Pará, Maranhão } \\
\text { e Ilhas de Cabo } \\
\text { Verde }\end{array}$ & Corveta \\
\hline Bela Baronesa & $\begin{array}{l}\text { José Gomes de Carva- } \\
\text { lho }\end{array}$ & 1776,1777 & Maranhão & Galera \\
\hline $\begin{array}{l}\text { Nossa Senhora da Iur- } \\
\text { sula (?) e Santo An- } \\
\text { tônio }\end{array}$ & . & 1776 & $\overline{\text { Maranhão }}$ & Sumaca \\
\hline $\begin{array}{l}\text { Nossa Senhora da Es- } \\
\text { perança e Santa Rita }\end{array}$ & & 1775 & Maranhão & Corveta \\
\hline São Zacarias & & 1776 & Maranhão & Corveta \\
\hline $\begin{array}{l}\text { Nossa Senhora dos } \\
\text { Prazeres }\end{array}$ & & 1774 & Maranhão & Sumaca \\
\hline $\begin{array}{l}\text { Santa Anna e Nossa } \\
\text { Senhora da Lapa }\end{array}$ & Veríssimo Duarte & 1774 & Maranhão & Galera \\
\hline $\begin{array}{l}\text { Nossa Senhora de } \mathrm{Na}- \\
\text { zaré e Santo Antônio }\end{array}$ & & 1775 & Maranhão & $\mathrm{Nau}$ \\
\hline $\begin{array}{l}\text { Nossa Senhora da Oli- } \\
\text { veira e Santa Anna - }\end{array}$ & & 1777 & Maranhão & Corveta \\
\hline $\begin{array}{l}\text { Santíssimo Sacramen- } \\
\text { to e Nossa Senhora da } \\
\text { Lapa }\end{array}$ & & $\overline{177} \overline{6}$ & Maranhāo & Corveta \\
\hline Divina Providência & Antônio de Souza Neto & 1778 & Maranhão & Corveta \\
\hline $\begin{array}{l}\text { Nossa Senhora da Luz } \\
\text { e São Pedro Gonçalves }\end{array}$ & $\cdot$ & 1776 & Maranhão & Corveta \\
\hline
\end{tabular}




\begin{tabular}{|c|c|c|c|c|c|}
\hline $\begin{array}{l}\text { Santa Rita e Santissi- } \\
\text { mo Sacramento }\end{array}$ & $\begin{array}{c}\text { Antônio Monteiro } \mathrm{Ne}- \\
\text { ves }\end{array}$ & . & 1778 & Maranhão & Galera \\
\hline $\begin{array}{l}\text { Nossa Senhora Mãe de } \\
\text { Deus e Santo Antônio }\end{array}$ & $\begin{array}{l}\text { Luís Antônio da Rocha } \\
\text { José Francisco Coito }\end{array}$ & & 1778 & $\begin{array}{l}\text { Maranhão } \\
\text { e Angola }\end{array}$ & Corveta \\
\hline $\begin{array}{l}\text { Nossa Senhora dos } \\
\text { Prazeres e Providência }\end{array}$ & $\begin{array}{l}\text { Manuel Vicente de } \\
\text { Carvalho } \\
\text { Joaquim José da Costa }\end{array}$ & & $\begin{array}{l}1777,1778 \\
1778\end{array}$ & Maranhão & Corveta \\
\hline $\begin{array}{l}\text { São Francisco de Pau- } \\
\text { la e Nossa Senhora da } \\
\text { Piedade }\end{array}$ & & & 1776 & Maranhão & Sumaca \\
\hline $\begin{array}{l}\text { Santo Cristo e Nossa } \\
\text { Senhora da Arrábida }\end{array}$ & & & 1777 & Maranhão & Corveta \\
\hline$\overline{\text { Santa Anna e São José }}$ & & & 1775 & $\begin{array}{l}\text { Pará, Maranhão } \\
\text { e Angola }\end{array}$ & Corveta \\
\hline $\begin{array}{l}\text { Nossa Senhora da Oli- } \\
\text { veira e Santos Reis } \\
\text { Magos. }\end{array}$ & Nanuel dos Santos & & $\overline{1773}$ & Maranhão & Corveta \\
\hline $\begin{array}{l}\text { São Luís, Rei de Fran- } \\
\text { ça }\end{array}$ & Ignácio Luís da Silva & & $\begin{array}{l}1773,1774,1777 \mathrm{e} \\
1778\end{array}$ & $\begin{array}{l}\text { Maranhão } \\
\text { e Angola }\end{array}$ & Corveta \\
\hline $\begin{array}{l}\text { Santa Anna e São Joa- } \\
\text { quim }\end{array}$ & $\begin{array}{l}\text { José de Oliveira Bu- } \\
\text { Ihão } \\
\text { Filipe de Aguiar }\end{array}$ & $3.910 \$ 272$ & 1777,1776 & $\begin{array}{l}\text { Maranhão } \\
\text { e Pará }\end{array}$ & Galera \\
\hline $\begin{array}{l}\text { Nossa Senhora do Sa- } \\
\text { cramento }\end{array}$ & $\begin{array}{l}\text { Joaquim Ribeiro } \\
\text { Feliciano dos Santos } \\
\text { Vitorino José da Silva }\end{array}$ & & $\begin{array}{l}1777 \\
1778\end{array}$ & $\begin{array}{l}\text { Maranhão e } \\
\text { Ilhas de } \\
\text { Cabo Verde }\end{array}$ & $?$ \\
\hline $\begin{array}{l}\text { Nossa Senhora do Car- } \\
\text { mo }\end{array}$ & $\begin{array}{l}\text { Joaquim da Costa } \\
\text { Antônio Raposo }\end{array}$ & & $\begin{array}{l}1777 \\
1774\end{array}$ & & $?$ \\
\hline
\end{tabular}




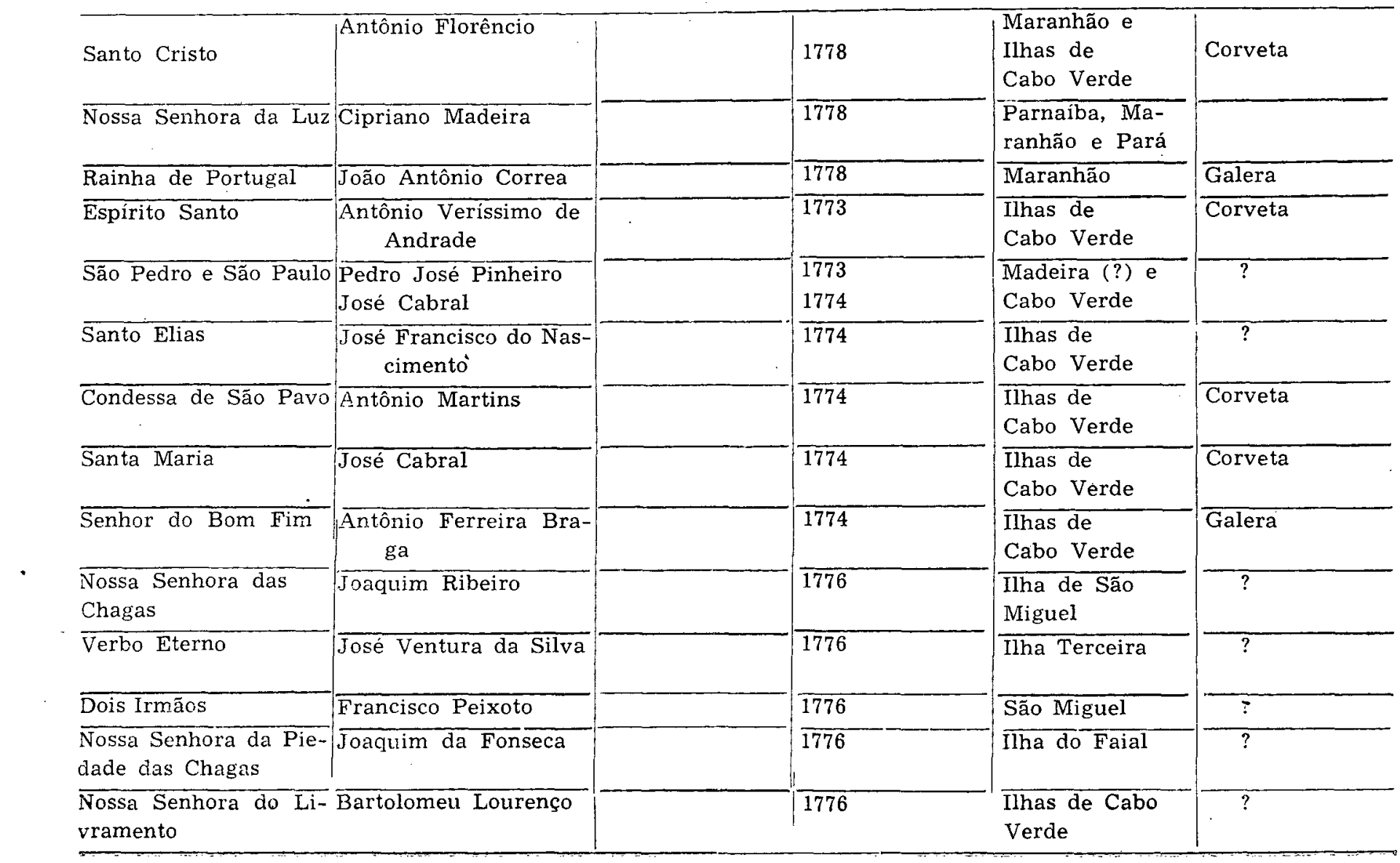




\begin{tabular}{|c|c|c|c|c|c|}
\hline $\begin{array}{l}\text { Nossa Senhora do So- } \\
\text { corro }\end{array}$ & Jacinto Gomes & & 1777 & $\begin{array}{l}\text { Ilhas de Cabo } \\
\text { Verde, Parnaiba } \\
\text { e Pará }\end{array}$ & Chalupa \\
\hline $\begin{array}{l}\text { Nossa Senhora da } \mathrm{Vi}- \\
\text { tória }\end{array}$ & Pedro José Pinheiro & & 1774,1777 & $\begin{array}{l}\text { Ilhas de São Mi- } \\
\text { guel e Santa } \\
\text { Maria }\end{array}$ & Lambote \\
\hline Deus "te salve" (?) & Francisco dos Santos & & 1777 & Ilhas & Chalupa \\
\hline Bom Jesus da Pedra & Pedro de Macedo & & $\overline{1778}$ & Ilha Terceira & Chalupa \\
\hline $\begin{array}{l}\text { São Francisco de Pau- } \\
\text { la }\end{array}$ & $\begin{array}{l}\text { Manuel da Silva } \\
\text { José da Silva }\end{array}$ & $176 \$ 256$ & $\begin{array}{l}1772 \\
1773\end{array}$ & Cacheu e Bissau & Hiate \\
\hline Bom Despacho & & & & Parnaíba e Pará & Chalupa \\
\hline Boa e Nova & & & & Parnaiba e Pará & Chalupa \\
\hline $\begin{array}{l}\text { Nossa Senhora da Pie- } \\
\text { dade }\end{array}$ & & & & Parnaíba e Pará & Chalupa \\
\hline $\begin{array}{l}\text { Nossa Senhora da } \\
\text { Guia }\end{array}$ & & & & Parnaíba e Pará & Chalupa \\
\hline Familia Sagrada & & & . & Parnaíba e Pará & Chalupa \\
\hline $\begin{array}{l}\text { Nossa Senhora da Con- } \\
\text { ceição e Santo Antônio }\end{array}$ & & & 1774 & Parnaiba e Pará & Sumaca \\
\hline $\begin{array}{l}\text { Nossa Senhora dos } \\
\text { Prazeres }\end{array}$ & & & & Parnaíba e Pará & Chalupa \\
\hline$\overline{\text { Santo Antônio e Alma }}$ & & & & Parnaíba e Pará & Chalupa \\
\hline São José & & & 1774 & Parnaíba e Pará & Lambote \\
\hline Santo Antônio & & $2.403 \$ 936$ & & Parnaíba e Pará & Galera \\
\hline $\begin{array}{l}\text { Nossa Senhora da } \mathrm{Pu}- \\
\text { rificação }\end{array}$ & & & & $\begin{array}{l}\text { Pará e } \\
\text { Maranhão }\end{array}$ & Sumaca \\
\hline $\begin{array}{l}\text { Nossa Senhora da } \mathrm{Ma}- \\
\text { dre de Deus }\end{array}$ & & $2.409 \$ 939$ & $\overline{1756}$ & Pará & $\overline{\text { Nau }}$ \\
\hline
\end{tabular}


de navios? Neste caso, como explicar a contabilidade dos Balanços onde surgem quatro embarcações adquiridas em diferentes épocas e por preços diversos? E a existência de uma sumaca e uma galera com o mesmo nome e capitão em 1759? Consoante a escrituração da emprêsa, não há dúvida: havia duas galeras, duas sumacas e uma chalupa sob a proteção de Nossa Senhora da Conceição. A primeira galera, adquirida por .... $5.149 \$ 448$ réis em 1760 , perdeu-se em 1769. Em 1771 a Companhia adquiriu outra pela quantia de $5.696 \$ 000$ réis. O mesmo sucederia em relação às duas sumacas: a primeira, adquirida em 1772 pela importância de $2.802 \$ 825$ réis, sairia do giro mercantil por diferentes razões, podendo, inclusive, ter naufragado; no ano seguinte, a Junta da Administração da emprêsa comprou outra por $3.147 \$ 025$ réis, para substituir a sua congênere desaparecida. E' o que se nos afigura plausível. A chalupa Nossa Senhora da Conceição, adquirida pela sociedade em 1774 pela quantia de $1.050 \$ 523$, não cria problema. Ainda bem. Resta, no entanto, a questão da sumaca e galera que navegam em 1759 sob o mesmo comando. E' claro que o capitão Antônio Pontes Lisboa podia ser comandante dos dois navios em épocas diferentes do mesmo ano de 1759 . Exato. Não obstante a praticabilidade do fato, impressiona sobremaneira tamanha coincidência - dois navios com o mesmo nome e capitão no mesmo ano. E' pouco provável, mas não é impossível tratar-se da mesma embarcação. Em 1759 a sumaca podia estar sendo restaurada em algum estaleiro. Ultimada a reforma, seria lançada ao mar como galera, conservando o mesmo nome - Nossa Senhora da Conceição. De uma ou de outra forma põe-se, realmente, o problema formudado.

Quer-nos parecer, outrossim, que alguns navios não pertenceriam ao patrimônio da Companhia. Alguns dêles seriam fretados. E' o que se nos afigura. O elevado número de embarcações recenseadas é deveras perturbador. Os quadros demonstrativos organizados com os elementos extraídos dos papéis da Companhia, não obstante o seu alto valor, acham-se incompletos. E' natural que assim seja, dada a escassez de fontes. Observe-se que não conseguimos averiguar todos os preços de custo dos barcos pertencentes à emprêsa. E' que nem todos figuram nas demonstrações dos Balanços da Companhia, cujas balizas são representadas pelos anos de 1760 e 1774 . Antes e depois dêstes marcos cronológicos da vida mercantil da sociedade é enormemente dificultoso, senão irrealizável, apurar as importâncias em dinheiro de todos os navios que en- 
grossaram as rotas atlânticas da gigantesca emprêsa ultramarina.

Depois de 1774, término da escrituração dos Balanços arrolados, coincidindo com o ritmo crescente das carregações exportadas dos portos das capitanias do Pará e Maranhão, a Companhia adquiriu respeitável número de navios. Vejam-se, por exemplo, os quadros demonstrativos onde figuram 20 corvetas, 5 galeras, 3 naus, 3 chalupas, 2 sumacas e 7 embarcações de tipos não identificados enriqueceram a frota da emprêsa entre os anos de 1775 e comêço de 1778 (22). Como nesse período não foram apurados os Balanços da Companhia, é natural que os montantes gastos pela emprêsa no aumento da sua marinha mercante não constam de nossas tabelas. Demais, nenhum dos papéis selecionados pertencentes à escrituração da emprêsa fornece melhores informes dos que figuram nos quadros elucidativos da tonelagem da frota da Companhia.

A partir dos seus primeiros dias de vida, a sociedade mercantil começou a formar a sua marinha, condição vital para o funcionamento do portentoso organismo.

A 13 de agôsto de 1755, a Junta da Administração comprou as galeras São José e Nossa Senhora da Conceição, construídas e reformadas na Inglaterra, a João Bristow, pelas respectivas importâncias de $4.842 \$ 552$ réis e $5.149 \$ 448$ réis (23).

Em 1756 a galera São José já navegava nas rotas de Belém, São Luís, Bissau e Cacheu, sob o comando do capitão José Ferreira de Azevedo, conforme se pode ver na tabela explicativa da tonelagem da frota da Companhia. Em 1762, porém, saiu do giro mercantil por ter naufragado nas proximidades da costa do Estado do Grão-Pará e Maranhão. O desafortunado comandante Luís Ferreira Braga, que conseguiu escapar com vida, foi prêso, sendo sôlto sòmente no dia 12 de abril de 1764 depois da Junta da Administração se convencer da sua inculpabilidade (24).

A 10 de fevereiro de 1756 a frota da Companhia foi enriquecida com a compra das naus "Santa Anna e São Francisco Xa-

\footnotetext{
(22). - Ultimado o prazo de vinte anos proposto para duração da Companhia. (Cf. Institutiçāo..., § 51), o privilégio não fol renovado. A Corôa, porém, permitiu-lhe a continuidade đo seu giro mercantil. A conjuntura do reino começava a mudar com a doença de $D$. José $I$ e a regência de $D$. Mariana Vitória de Bourbon. De 1775 em diante, todavia, é que a Companhia engrossou as suas rotas, fato demonstrativo do aumento da tonelagem da sua frota nesse periodo.

(23). - A.H.M.F. - D.C.G.P.M. - A. Registros n.os 4 e 5.

(24). - Ibidem, L.R.R.C.G.P.M. n.॰ 1, fol. 55.
} 
vier" e "Nossa Senhora da Madre de Deus, São José e Almas" adquiridas, respectivamente, pelas quantias de $11.679 \$ 408$ réis: e $10.267 \$ 728$ réis (25). No dia seguinte, os deputados da Junta, Estêvão José de Almeida e Manuel Ferreira da Costa, compraram a galera "Nossa Senhora da Atalaia e Senhora do Bom: Fim", a Antônio José Rodrigues e Bento Fernandes Lobo, por $5.192 \$ 208$ réis; entrou logo na rota do Pará e Maranhão (26).

Nos restantes meses de 1756, a Companhia adquiriu mais. os seguintes navios: a 13 de maio a galera "São Pedro" foi. comprada a Cristóvão Hake pela importância de $3.614 \$ 676$ réis; em 2 de outubro, a galera "Santa Anna e São Joaquim" foi negociada com José Rodrigues Esteves pelo preço de $3.910 \$ 272$ réis; a galera "São Sebastião" foi comprada em 23 de outubro a Elias Perachon por $3.724 \$ 999$ réis; dias depois já navegava para Bissau, Pará e Maranhão, sob o comando do capitão Manuel. Gomes; pelo preço de $2.403 \$ 936$ réis foi adquirida a galera "Santo Antônio", a 7 de agôsto, a João Aires; um mês depois, a 7 de setembro, a Companhia comprou ao marquês de Abrantes. o hiate "São Francisco de Paula" por 176\$256 réis; no dia anterior os deputados da Junta haviam adquirido a galera "São Luís" a Félix Teixeira Neto pela importância de $5.353 \$ 857$ réis; em 1759 era comandada pelo capitão José de Carvalho, que. traficava na rota do Pará e Maranhão; o corsário "Santo Estê-. vão" foi adquirido em leilão pela quantia de $1.086 \$ 830$ réis; no comêço de novembro foi comprado em leilão público, em casa de "Arbouin \& Cia.", o paquete "São Miguel" pelo preço de $957 \$ 576$ réis, navegando dias depois para os portos de Belém e São Luís, sob o comando do capitão Antônio Alves de Carvalho (27).

A 17 de outubro de 1757, a Junta da Administração da Companhia comprou a José Pinto Vieira a corveta "Nossa Senhora da Esperança" por $3.676 \$ 080$ réis. Nesse mesmo ano já navegava para Bissau, Cacheu, Pará e Maranhão, sob o comando do capitão José dos Santos. No dia 7, os deputados da emprêsa já haviam arrematado em leilão o bergantim "São Tomé" pela importância de 521\$832 réis, encontrando-se nesse mesmo ano nas rotas das capitanias do extremo-norte do Brasil e nas da Guiné (28). O último registo de que se tem notícia data de 12 de abril de 1759, dia em que o govêrno da Companhia comprou a.

\footnotetext{
(25). - midem, D.C.G.P.M. - A. regitros n. ${ }^{\circ} 31$ e 32 .

(26). - Ibidem, idem, registro n.o 33.

(27). - Ibidem, idem, registros $n .^{\circ}$ s 205, 218, 214, 215, 216, 217, 514 e 875 .

(28). - Ibidem, idem, registros n. ${ }^{\circ} 873$ e 874 .
} 
Simão Antônio a lancha "Nossa Senhora da Penha de França" pelo preço de $612 \$ 000$ réis, conforme se lê no "Diário $A$ " da poderosa emprêsa colonial, guardado no Arquivo Histórico do Ministério das Finanças, em Lisboa (29)..

Nada menos que 124 nomes de navios foram apurados. Veja-se o mapa esclarecedor da tonelagem da extraordinária frota. Salvo êrro de cômputo ou leitura de nossa parte, ou duplicação de nomes, os comboios da Companhia compunhamse de 35 corvetas, 20 galeras, 20 chalupas, 9 naus, 9 sumacas, 5 hiates, 4 navios, 3 escunas, 3 bergantins, 3 lambotes, 2 lanchas, um paquete, um corsário e mais $\mathbf{9}$ navios de tipos não identificados (30).

Esses navios navegavam nas rotas do Estado do Grão-Pará e Maranhão, cujo giro mercantil era completado pelas linhas de navegação atlântica de Bissau, Cacheu, Angola e Ilhas de Cabo Verde. A Companhia, no entanto, estendia, por vêzes, conforme as circunstâncias, as suas carreiras marítimas até ao Indico afro-asiático, Pacífico chinês e a diversos pontos do litoral brasileiro - Parnaíba, Bahia e Rio de Janeiro (31). Completando o tráfico atlântico à distância, a emprêsa organizou o comércio de cabotagem nas costas da Guiné, de Angola e do Brasil, onde certas áreas geo-econômicas eram patrulhadas por navios de guerra pertencentes ao patrimônio da própria emprêsa colonial.

Naus, galeras, sumacas e corvetas, navios de maior tonelagem e resistência, operavam nas rotas mais difíceis e arriscadas: de Lisboa, Cacheu, Bissau, ilhas de Cabo Verde e Angola, para os portos de Belém e São Luís. O giro era completado com a torna-viagem do Estado do Grão-Pará e Maranhão para o reino. As grossas correntes do tráfico eram constituídas pelas carregações de mão-de-obra africana, pelas exportações das mercadorias tropicais das capitanias do alto-norte do Brasil e pelos artigos de procedência européia.

As embarcações de menor capacidade eram empregadas no trânsito de cabotagem, representadas, sobretudo, pelas chalupas da costa do Brasil, que conduziam carnes da Parnaíba para os portos do Pará e Maranhão, e pelos lambotes, hiates e chalupas que traficavam entre a Guiné e ilhas de Cabo Verde com panos, escravos e comestíveis (32).

(29). - Midem, idem, registro n.o 177.

(30). - Veja-se o quadro demonstrativo da tonelagem da frota da Companhia.

(31). - Cf. Demonstraçōes in A.H.M.F. - L.B.C.G.P.M.

(32). - Em 1774 as embarcaçōes pequenas que giravam na Guiné, fazendo o trá- 
Graças aos papéis avulsos da "Caixa do Pará", número 37, guardada no Arquivo Histórico Ultramarino, em Lisboa (33), pode-se ter uma idéia aproximada da tonelagem da frota da Companhia durante o seu giro mercantil, que se estendeu de agôsto de 1755 a janeiro de 1778 . Veja-se o porte dos navios abaixo relacionados:

Navios

Nau Grão-Pará $\ldots \ldots \ldots \ldots \ldots \ldots \ldots \ldots \ldots \ldots \ldots \ldots \ldots \ldots \ldots \ldots$

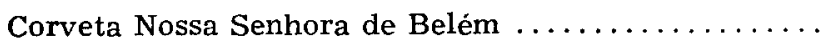

Galera Santa Anna e São Joaquim ............ 500

Galera Nossa Senhora da Conceição (qual delas?) .. 350

Corveta Santo Antônio, o Delfim ............ 350

Corveta Nossa Senhora do Monte do Carmo ........ 300

Corveta São Francisco de Paula ............. 250

Corveta São Francisco Xavier .............. 250

Corveta São Pedro Gonçalves ............... 200

Corveta Nossa Senhora da Oliveira ........... 200

Se atribuirmos o porte médio de 350 toneladas a cada um dos 124 navios apurados, verifica-se que a Companhia foi senhora de uma gigantesca frota mercante de 43.400 toneladas. $\mathrm{E}$, note-se, o cômputo não é nada exagerado. Ao contrário, afigura-se-nos modesto, tendo-se em conta o elevado número de corvetas e galeras, navios de grande pêso e, certamente, de boa capacidade de transporte. Se alguma exageração existe, devese, isso sim, à enorme lista de nomes de navios, não ao nosso cálculo. Não obstante, é sobremaneira provável que a tonelagem da frota seja menor, dada a possível duplicação de nomes de navios. De qualquer forma, o resultado apurado é enormemente expressivo.

As diferentes demonstrações do mencionado Livro dos Balanços da Companhia ministram preciosos e.informativos subsídios que nos permitem afirmar o poderio da frota durante o

fico de cabotagem, eram as seguintes: um hiate (Nossa Senhora da Boa Nova), duas Chalupas (Nossa Senhora da Conceição e Santo Antônio e Nossa Senhora da Vida) e três lambotes $\rightarrow$ São José, Nossa Senhora da Glória e Nossa Senhora da Vitória. (Cf. L.B.C.G.P.M. Liv. n.o 76, 1774). (33). - A.H.U. - C. P. n.0 37 (1777-1778). 
CUSTO DA FROTA DA COMPANHIA

(1759-1774

\begin{tabular}{|c|c|c|c|c|c|}
\hline \multirow{2}{*}{ Anos } & \multicolumn{3}{|c|}{ NAVIOS } & \multirow{2}{*}{$\begin{array}{l}\text { Custo dos navios } \\
\text { (réis) }\end{array}$} & \multirow{2}{*}{ Observações } \\
\hline & Existentes & Construidos & Perdjdos & & \\
\hline 1759 & 13 & - & - & $52.868 \$ 392$ & - \\
\hline 1760 & 15 & 2 & - & $58.191 \$ 866$ & - \\
\hline 1761 & 20 & 5 & - & $73.441 \$ 217$ & - \\
\hline 1762 & 20 & - & - & $73.441 \$ 217$ & $\begin{array}{l}\text { Devolvida à Co- } \\
\text { rôa a nau de } \\
\text { Guerra N. S. da } \\
\text { Atalaia }\end{array}$ \\
\hline 1763 & 20 & 1 & 1 & $87.173 \$ 586$ & - \\
\hline 1764 & 21 & 1 & - & $101.719 \$ 059$ & - \\
\hline 1765 & 22 & 1 & - & $105.803 \$ 073$ & - \\
\hline 1766 & 22 & 1 & - & $107.049 \$ 819$ & - \\
\hline 1767 & 24 & 3 & 1 & $107.993 \$ 872$ & - \\
\hline 1768 & 26 & 5 & 3 & $127.348 \$ 961$ & - \\
\hline 1769 & 25 & - & 1 & $121.078 \$ 199$ & - \\
\hline 1770 & 24 & - & 1 & $117.072 \$ 289$ & - \\
\hline 1771 & 26 & 2 & - & $123.891 \$ 585$ & - \\
\hline 1772 & 27 & 2 & 1 & $131.950 \$ 074$ & - \\
\hline 1773 & 29 & 4 & 2 & $133.931 \$ 648$ & - \\
\hline 1774 & 32 & 6 & 3 & $130.209 \$ 382$ & - \\
\hline
\end{tabular}


PERDAS DE NAVIOS DA COMPANHIA

(Naufragados e apreendidos)

\begin{tabular}{|c|c|c|c|c|c|c|c|c|}
\hline $\begin{array}{c}\text { Anos das } \\
\text { perdas }\end{array}$ & $\begin{array}{l}\text { Nomes dos } \\
\text { navios }\end{array}$ & Tipo & $\begin{array}{l}\text { Custo } \\
\text { (réis) }\end{array}$ & $\begin{array}{l}\text { Custeio } \\
\text { (réis) }\end{array}$ & $\begin{array}{c}\text { Valores } \\
\text { das cargas } \\
\text { (réis) }\end{array}$ & \begin{tabular}{|c|} 
Recupera- \\
ção (Segu- \\
ros e \\
fretes)
\end{tabular} & $\begin{array}{c}\text { Total do } \\
\text { prejuizo } \\
\text { (réis) }\end{array}$ & Observaçōes \\
\hline $\begin{array}{l}1763 \\
1768 \\
1770\end{array}$ & $\begin{array}{l}\text { São José } \\
\text { São Domingos } \\
\text { N. S. das Neces- } \\
\text { sidades }\end{array}$ & $\begin{array}{l}\text { Galera } \\
\text { Galera } \\
\text { Corveta }\end{array}$ & $\begin{array}{l}4.842 \$ 552 \\
1.882 \$ 308 \\
4.005 \$ 910\end{array}$ & $\begin{array}{l}2.386 \$ 756 \\
5.426 \$ 814 \\
5.032 \$ 389\end{array}$ & $\begin{array}{c}14.662 \$ 987 \\
7.016 \$ 544\end{array}$ & $\begin{array}{c}- \\
5.376 \$ 457 \\
4.105 \$ 640\end{array}$ & $\begin{array}{r}21.892 \$ 295 \\
1.937 \$ 665 \\
11.947 \$ 203\end{array}$ & $\begin{array}{l}\text { Naufragou nas } \\
\text { costas do Pará } \\
\text { Prêsa dos arge- } \\
\text { linos } \\
\text { Naufragou }\end{array}$ \\
\hline \multicolumn{3}{|c|}{ SOMA } & $10.730 \$ 770$ & $12.845 \$ 959$ & $21.679 \$ 531$ & $9.482 \$ 097$ & $35.777 \$ 163$ & \\
\hline
\end{tabular}


PERDAS DE NAVIOS DA COMPANHIA PELA AÇÃO DO TEMPO

\begin{tabular}{|c|c|c|c|c|c|c|c|}
\hline $\begin{array}{l}\text { Anos das } \\
\text { perdas }\end{array}$ & $\begin{array}{c}\text { Nomes dos } \\
\text { navios }\end{array}$ & Tipo & $\begin{array}{l}\text { Custo } \\
\text { (réis) }\end{array}$ & $\begin{array}{l}\text { Recupera- } \\
\text { ção (réis) }\end{array}$ & $\begin{array}{c}\text { Total da perda } \\
\text { (réis) }\end{array}$ & $\begin{array}{l}\text { Custelo } \\
\text { (réis) }\end{array}$ & Observações \\
\hline 1767 & São Tomé & Bergantim & $521 \$ 832$ & - & $521 \$ 832$ & - & Desmanchado \\
\hline 1768 & São Marçal & $"$ & $1.626 \$ 798$ & $680 \$ 000$ & $946 \$ 798$ & 一 & $\eta$ \\
\hline 1768 & $\begin{array}{l}\text { N. S. da Espe- } \\
\text { rança }\end{array}$ & Corveta & $3.675 \$ 080$ & $730 \$ 000$ & $3.405 \$ 786$ & $459 \$ 706$ & $\Rightarrow$ \\
\hline 1769 & $\begin{array}{l}\text { N. S. da Concei- } \\
\text { ção (II) }\end{array}$ & Galera & $5.149 \$ 448$ & $1.240 \$ 000$ & $3.909 \$ 448$ & - & $\begin{array}{l}\text { Encalhada em } \\
\text { terra }\end{array}$ \\
\hline 1772 & Santo Antônio & $"$ & $2.403 \$ 936$ & - & $2.403 \$ 936$ & - & Desmanchada \\
\hline 1773 & São Lázaro & $"$ & $2.637 \$ 312$ & $698 \$ 324$ & $1.938 \$ 988$ & 一 & $"$ \\
\hline 1773 & São João Batista & $"$ & $2.700 \$ 745$ & $599 \$ 543$ & $2.101 \$ 202$ & - & $"$ \\
\hline 1774 & São Pedro & $"$ & $3.614 \$ 676$ & $768 \$ 860$ & $2.845 \$ 816$ & $\longrightarrow$ & $"$ \\
\hline .1774 & N. S. do Cabo & $"$ & $6.469 \$ 248$ & $2.324 \$ 300$ & $4.144 \$ 948$ & $\ldots$ & $"$ \\
\hline 1774 & São Sebastião & $"$ & $3.724 \$ 999$ & $1.055 \$ 983$ & $2.669 \$ 016$ & - & $"$ \\
\hline \multicolumn{3}{|c|}{ SOMA } & $32.525 \$ 074$ & $8.097 \$ 020$ & $24.887 \$ 760$ & $459 \$ 706$ & \\
\hline
\end{tabular}


tempo que se estende de 1759 a 1774 , bem como os montantes. que a Junta da Administração da emprêsa despendeu na montagem da sua marinha mercante e as perdas de navios naufragados, apreendidos ou desmanchados pela ação do tempo. Os. quadros seguintes, organizados com os elementos da referida. escrituração da Companhia, são deveras elucidativos.

Foram poucos os navios da Companhia que naufragaram: apenas dois em trinta e dois - 6\%. Trata-se da galera São. José e da corveta Nossa Senhora das Necessidades, naufragadas, respectivamente, em 1763 e 1770 .

$O$ restante da frota subsiste. São barcos construídos pela própria Companhia, mais resistentes, de maior capacidade $\mathrm{e}$ mais caros.

As perdas pela ação do tempo são sòmente dos primeiros navios, de menor tonelagem, mais baratos e adquiridos em segunda mão.

Nove barcos foram desmanchados: dois bergantins (São. Tomé e São Marçal), uma corveta (Nossa Senhora da Esperança) e seis galeras - Nossa Senhora da Conceição (II), São Lázaro, São João Batista, São Pedro, Nossa Senhora do Cabo e São Sebastião. Apenas uma galera (Santo Antônio) ficou encalhada em terra, em 1772. A Companhia conseguiu ainda recuperar $25 \%$ do valor das perdas de navios - 8.097\$020, como. se vê no mapa anexo. Sòmente um navio - a galera São Domingos - foi prêsa da pirataria, no ano de 17.68 , consoante registro dos Balanços da emprêsa mercantil.

As duas naus de guerra - Nossa Senhora da Atalaia e Nossa Senhora das Mercês -, doadas, como ficou dito, pela Corôa à Companhia em 1755, embora computadas no número, não o foram no valor. Em 1762, a Junta da Administração devolveu à realeza uma delas - a nau Nossa Senhora da Atalaia - que passou a engrossar a Armada Real.

A Companhia gastou na montagem da sua marinha mercante mais de cento e trinta contos de réis - $130.209 \$ 382$ réis, algarismos expressivos que falam por si melhor que quaisquer outros argumentos. Se acrescentarmos a essa respeitável importância em dinheiro a quantia de $43.255 \$ 834$ réis, correspondente à perda de navios, verifica-se que a emprêsa teve um. dispêndio total de $173.465 \$ 216$ réis. A Companhia perdeu, portanto, $25 \%$ daquele valor.

Em 1759 a emprêsa possuia 13 navios no valor de $52.868 \$ 392$. réis. Em 1774, último ano dos Balanços, a Companhia já man- 
tinha uma poderosa marinha mercante composta por 32 embarcaçōes no valor de $130.209 \$ 382$ réis, tendo perdido, no entanto, treze navios que haviam custado $43.255 \$ 834$ réis, conforme consta das demonstrações dos Balanços da emprêsa. O engrossamento da frota da Companhia figura no quadro elucidativo do seu custo.

Os navios mencionados nos quadros demonstrativos da tonelagem da frota -20 corvetas, 5 galeras, 3 naus, 3 chalupas, 2 sumacas e mais 7 barcos de tipos não identificados (34) - não figuram no custo dos comboios da Companhia, por serem posteriores ao ano de 1774, período da descontabilização da prestigiosa emprêsa colonial. O último Balanço data de 1774. Depois dêste ano, a escrituração da Companhia não registra mais os montantes dos custos dos navios. O giro mercantil, no entanto, cresce admiràvelmente. Por isso mesmo a sociedade engrossou a sua marinha mercante com mais quarenta barcos (35).

Se atribuirmos a cada um dêstes últimos quarenta navios o preço médio de $2.5000 \$ 000$ réis, montante que não se nos afigura exagerado, tendo-se em conta que alguns navios no período anterior a 1775 custaram maís de dez contos de réis (36), verifica-se que a Companhia dispendeu, na "nova fase" do seu giro mercantil (1775-1778), uma importância de .... $100.000 \$ 000$ réis. Somada à quantia gasta na "primeira fase" (1759-1774), apura-se a extraordinária cifra de $273.465 \$ 216$ réis, importância que a Companhia desembolsou na montagem de sua marinha mercante.

Os diversos tipos de navios, embora destinados ao giro mercantil de longo curso, com bons resultados para a emprêsa, eram, alguns dêles, aproveitados em cobertura de guerra sempre que as circunstâncias a isso obrigassem. Não eram, porém, navios verdadeiramente de combate, mas prestavam bons serviços na defesa militar dos comboios e de alguns pontos de certas áreas geo-econômicas do rico patrimônio ultramarino da Corôa, permanentemente desejadas pelas grandes potências mercantilistas.

A construção de navios e o necessário levantamento do pessoal para a equipagem das frotas era regulada pelos parágrafos dez, onze e doze dos estatutos da Companhia. Navios

(34). - Vejam-se as relações dos navios apurados.

(35). - Ct. quadros demonstrativos.

(36). - Tbidem, idem. 
mercantes e de guerra podiam ser fabricados nos estaleiros do reino e do ultramar senhoreados pela gigantesca emprêsa colonial (37). Mediante licença da realeza, a Companhia podia convocar gente de mar e guerra necessária para guarnição dos seus comboios e navios que andavam nas costas do Brasil, da Africa e das ilhas (38). A Junta de Administração da Companhia a Corôa deu o privilégio de escolher os comandantes para os seus navios e "Capitaens de Mar e Guerra, e mais Officiaes que lhe parecer, para o govêrno e guarnição das Naos que armar" (39). As nomeaçõés eram por um ano, sendo que a mantença nos postos de comando resultava da "satisfação que se espera" (40). Tudo dependia, é claro, de confirmação régia. Os oficiais prestavam serviços à Companhia como se estivessem na "Real Armada", sendo, evidentemente, pagos pela emprêsa (41) .

Para que se tenha uma idéia aproximada das despêsas da Companhia com o sustento da sua frota mercante, organizamos o quadro elucidativo seguinte com os elementos extraídos de um dos "Maços do Maranhão" guardados no Arquivo Histórico Ultramarino, em Lisboa (42). Veja-se, por exemplo, o que a emprêsa colonial despendeu com a corveta "Nossa Senhora da Oliveira", na viagem de Cacheu para São Luís, a 11 de março de 1774, segundo registro de despêsa assinado por Filipe Damazio, administrador da Companhia naquele centro de resgate da Guiné (43).

Relação das despêsas da Companhia com a corveta Nossa Senhora da Oliveira na viagem de Cacheu para o Maranhão (11 de março de 1774)

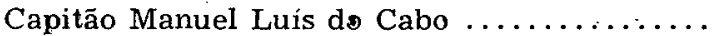
Valor mensal (réis)

Pilôto Joaquim Antônio da Costa ...........

Capelão Padre Bernardino de Sena ..........

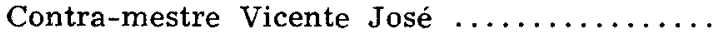

Cirurgiāo Manuel Gomes de Carvalho .........

Calafete Domingos Gonçalves ............

$\begin{array}{rr}12 \$ 000 & 93 \$ 330 \\ 10 \$ 000 & 22 \$ 000 \\ 9 \$ 000 & 18 \$ 660 \\ 8 \$ 000 & 18 \$ 000 \\ 8 \$ 000 & 14 \$ 920 \\ 14 \$ 920\end{array}$

(37). - Cf. Instituiçāo, § 10, pág. 6.

(38). - "a todo o tempo que lhe convier, fazendo-lhe as pagas e vantagens que acordar com elles. E succedendo que na mesma occasiāo mande $V$. Ma. gestade fazer levas de gente, precedendo as do serviço Real, se seguirãı logo immediatamente as da Companhia. Porem havendo urgente necessidade nella, consultará a V. Magestade, para que se sirva de lhe dar a necessária providência". (Ibidem, $\$ 11$, págs. 6 e seg.).

(39). - Tbidem, § 12, pág. 7.

(40). - Ibidem, idem

(41). - Ibidem, idem.

(42). - A.H.U. - M.M. n.o 29 (1774-1775).

(43). - Ibidem, idem. 
Tanoeiro Francisco José $\ldots \ldots \ldots \ldots \ldots \ldots \ldots$

$6 \$ 000$

$11 \$ 200$

Luís Lourenço, marinheiro ..............

$6 \$ 000$

$11 \$ 200$

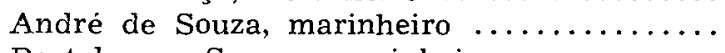

$6 \$ 000$

$11 \$ 200$

Bartolomeu Soares, marinheiro ...........

$6 \$ 000$

$11 \$ 200$

Estanislau de Almeida, marinheiro .........

$6 \$ 000$

$11 \$ 200$

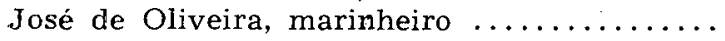

$5 \$ 812$

$10 \$ 956$

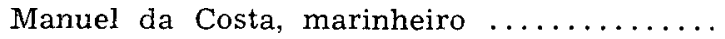

$5 \$ 812$

$10 \$ 956$

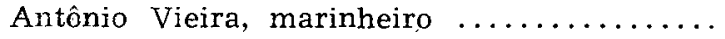

$5 \$ 812$

$10 \$ 956$

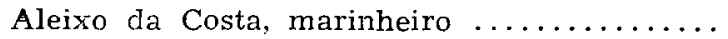

$5 \$ 250$

$9 \$ 800$

Antônio da Silva, marinheiro $\ldots \ldots \ldots \ldots \ldots$

$5 \$ 250$

$9 \$ 800$

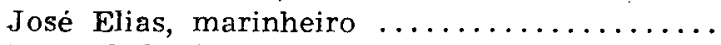

$4 \$ 875$

$9 \$ 087$

Manuel de Azevedo, marinheiro ...........

$4 \$ 875$

$9 \$ 087$

Euzébio Luis, marinheiro $\ldots \ldots \ldots \ldots \ldots \ldots$

$4 \$ 875$

$9 \$ 087$

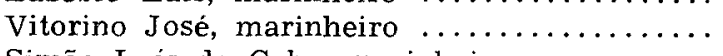

$4 \$ 500$

$8 \$ 400$

Simão Luis do Cabo, marinheiro ...........

$4 \$ 500$

$8 \$ 400$

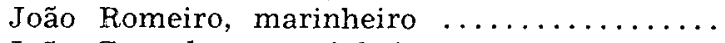

$4 \$ 125$

$7 \$ 687$

João Gonçalves, marinheiro $\ldots \ldots \ldots \ldots \ldots \ldots$

$6 \$ 287$

Manuel José da Costa, marinheiro ..........

$3 \$ 375$

$5 \$ 600$

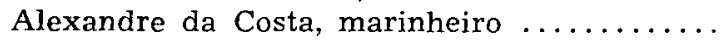

$3 \$ 000$

$5 \$ 600$

Manuel Gonçalves, marinheiro ...........

$5 \$ 600$

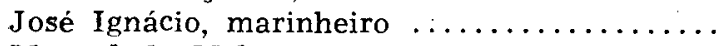

$5 \$ 600$

Manuel de Melo, marinheiro ..............

$3 \$ 00$

$5 \$ 600$

$3 \$ 625$

Manuel da Silva ("faleceu em 10 de fevereiro")

$21 \$ 000$

"De ir buscar o pilôto da barra" ...........

$9 \$ 500$

Total $\ldots \ldots \ldots \ldots \ldots$

$410 \$ 458$

Acrescente-se a êsse gasto da equipagem da corveta o que a Companhia desembolsou com comestíveis da tripulação (44) e despêsas miúdas, e compreenderemos melhor o preço da mantença das 124 embarcações que operavam nas linhas de longo curso do Atlântico afro-brasileiro e no comércio de cabotagem das costas da Guiné, do Brasil e de Angola, em grandiosos feixes de rotas ultramarinas a distância, que fizeram a fortuna da emprêsa pombalina e de certas áreas geo-econômicas do rico patrimônio da Corôa, na segunda metade do maneiroso século XVIII.

\section{MANUEL NUNES DIAS}

Livre-docente e Assistente da Cadeira de História da Civilização Moderna e Contemporânea da Faculdade de Filosofia, Ciências e Letras da Untversidade de São Paulo.

(44). - Certos "costeamentos" dos navios que navegavam nas rotas da Guiné Cacheu e Bissau - e Angola ultrapassavam a importáncia de $400 \$ 000$ réis em gêneros. 


\section{ABREVIATURAS}

C.N.C.G.P.M. - Cartas para o Norte da Companhia do Grão-Pará e Maranhão.

C. P. - Caixas do Pará.

D.C.G.P.M. - Diário da Companhia do Grão-Pará e Maranhão.

I. B.C.G.P.M. - Livros dos Balanços da Companhia do Grão-Pará e Maranhão.

L.R.E.C.C.G.P.M. - Livro de Registro do Expediente da Contadoria da Companhia do Grão-Pará e Maranhão.

L.R.R. - Livro das Resoluções Régias.

L.Cr.C.G.P.M. - Livro das Curregações da, Companhia do GrãoPará e Maranhão.

L.C.C.G.P.M.E. - Livro das Cargas da Companhia do Grão-Pará e Maranhão por Entrada.

M.M. - Maços do Maranhão

M.N. - Marco dos Navios.

M. - Memorial.

\section{FONTES}

I - Manuscritas.

Arquivo Histórico do Ministério das Finanças (Lisboa).

Cartas para o Norte da Companhia. Códices n. ${ }^{\circ}$ s 96 e 99.

Diário da Companhia - A.

Livro dos Balanços da Companhia do Grão-Pará e Maranhão. Códice n. ${ }^{\circ} 76$.

Livro das Carregações da Companhia do Grão-Pará e Maranhão. Códice n. ${ }^{\circ} 45$.

Livro das Cargas dos Navios da Companhia por Entrada. Códice $n .^{\circ} 73$.

Livro das Resoluções Régias $n .^{\circ} 1$.

Livro de Registro do Expediente da Contadoria da Companhia. Códice n. ${ }^{\circ} 91$.

Memorial A. Códice n..$^{\circ} 62$.

Arquivo Histórico Ultramarino (Lisboa).

Caixas do Pará n. ${ }^{\circ} 33$ (1772).

Caixas do Pará n. ${ }^{\circ} 35$ (1774-1776).

Caixas do Pará n..$^{\circ} 37$ (1777-1778).

Caixas do Pará n. ${ }^{\circ} 38$ (1778).

Maços do Maranhão n. ${ }^{\circ} 25$ (1760-1764).

Maços do Maranhão n. ${ }^{\circ} 26$ (1764-1769).

Maços do Maranhão n. 28 (1772-1773).

Maços do Maranhão n. ${ }^{\circ} 29$ (1774-1775).

Maços do Maranhão n. ${ }^{\circ} 30$ (1775-1777).

Maços do Maranhão n. ${ }^{\circ} 31$ (1778-1779).

Arquivo da Câmara Municipal de Lisboa.

Marco dos Navios. Livros n. ${ }^{\circ}$ s 1,2 e 4 (1772-1778).

II - Impressas.

Instituição da Companhia Geral do Grão-Pará e Maranhão. Lisboa, 1775 . 